\title{
The Impacts of the Global Financial Crisis on Southeast Asian Equity Markets Integration
}

\author{
Tran Phuong Thao and Kevin Daly
}

\begin{abstract}
An interesting question which this paper attempts to investigate is whether the relationships between Asian equity markets have changed as a result of the Global Financial Crisis (GFC). The paper investigates the long-run relationship among six equity markets in the Southeast Asian region, namely Thailand, Malaysia, Singapore, Philippines, Indonesia and Vietnam using daily market indices collected over the period 2006 - 2010. The objective of the research was to uncover the latest empirical evidence from a study of the long run relationships amongst the equity markets of South East Asia with a view to understanding the probable impact of the recent Global Financial Crisis on those markets. Three testing methods were used namely; bivariate cointegration test based on residuals, multivariate cointegration test based on vector autoregressive (VAR) model and cointegration tests with the presence of structural breaks. The results reveal evidence that a number of bi-directional long-run relationships exists among several of these markets, including the markets of Thailand and Indonesia; Thailand and Singapore and Philippine and Malaysia in both pair-wise cointegration tests with and without the presence of a structural break. The study found evidence of mono-cointegrations in the case of Vietnam's equity market and the other markets of South East Asia. These results have implications for investors in these markets in terms of diversification of risks and returns where shocks to any one market may or may not have a contagious effect on other markets in the region.
\end{abstract}

Index Terms-Equity market linkage, long run relationship, global financial crisis, Southeast Asian markets.

\section{INTRODUCTION}

This paper examines the long run relationships between the emerging equity markets of Southeast Asia over the period 2006 - 2010. The objective of this study is to investigate whether the pronounced benefits of portfolio diversification namely a reduction in risk and increase in expected returns has changed over a period which covers the global financial crisis. The advantages of portfolio diversification arise from low correlations across equity market returns which in part are caused by factors such as barriers to international trade and investments, poor quality of information on foreign equity markets or simply home investor bias. Given that significant changes have occurred across Asian equity markets since the Asian financial crash and the more recent Global Financial crisis (GFC) it appears timely to investigate whether the relationships between these markets has changed over these major crises. The 2007

Manuscript received May 22, 2012; revised July 5, 2012.

T. P. Thao is with the Securities Business Department, Faculty of Banking, University of Economics Ho Chi Minh City, Vietnam (email: tranthao@ueh.edu.vn).

K. Daly is with the School of Business, University of Western Sydney, Australia. (e-mail: k.daly@uws.edu.au). global financial crisis has been documented as one of the most severe crises due to its overwhelming negative impact on equities, real estate, foreign exchange and capital markets [1]-[3]. A study by Bartram and Bodnar [3] show that the GFC created the conditions for the current credit crisis with an increased risk premia been imposed on lending across the global banking sector. The crisis had an almost instantaneouse negative impact on equity markets with emerging equity markets been particularly impacted.

Equity market integration todate has been researched during the aftermath of the Asian Financial crises [4]-[6]; rather than the GFC. This paper attempts to answer the following questions: Firstly, has the long run relationships across Asian Equity markets changed since 2007? Secondly what do the dynamic relationships between markets over the period indicate? Thirdly has the return and volatility transmission process between these Southeast Asian markets changed over the period? Hence, this paper aims to investigate the linkages among equity markets in the South East Asian region before during and after the GFC. The paper is organized as follow. Section 1 provides an introduction. Section 2 discusses previous research. Section 3 describes methodology and data collection. Section 4 summarized findings and discussions. Section 5 concludes the paper.

\section{Previous Research}

Studies, which specifically focus on long-run relationships between stock markets after a shock, test for changes in the co-integrating relationships between stock markets. Arshanapalli and Doukas [7] employ cointegration techniques to examine the linkages and dynamic interactions among stock price indices across the major world exchanges over a period pre and post-October 1987. Their evidence indicates that the degree of international co-movements between stock market indices has changed significantly since the October $1987 \mathrm{crash}$. In particular, they note that over the post-1987 crash period, three European markets (France, Germany and the U.K.) were strongly linked (cointegrated) with the U.S. stock market, which is in direct contrast to the pre-1987 period results. Allen and MacDonald [8] investigated the benefits available from international stock market portfolio diversification to Australian investors by conducting bivariate cointegration tests between Australia and other national stock market indices. Employing both Engle and Granger [17] and Johansen [18] estimation techniques, the overall evidence from the above study points to only slight support for cointegration amongst the stock market indices considered.

Equity market linkages are examined in a number of 
studies such as Lucey and Voronkova [9], Huyghebaert and Wang [10], and Cheung et al., [11], however, findings among the studies are mixed and inconclusive. In fact, while some studies show that relationships among markets are likely to have significant effects on neighboring or regional markets, other studies find contradictory results. Chen, Firth and Rui [12], for example, use data from 1995 to 2000 to examine the stock market cointegration of six countries in Latin America, namely Argentina, Brazil, Chile, Colombia, Mexico, and Venezuela, and they find long-term equilibrium relationship among markets. The existence of cointegration is explained by the fact that Latin American countries have adopted several deregulations, privatization plans and trade alliances. Another study by Huang, Yang and $\mathrm{Hu}$ [2] investigates the cointegration with an emphasis on structural breaks caused by the Asian financial crisis and finds no supporting evidence for the notion of co-integrating relationships amongst the markets of the China Growth Triangle, including Hong Kong, Shanghai, Taiwan and Shenzhen markets despite their intensified intra-regional trades. More recently, Nieh [13] investigated the effect of the Asian crisis on the inter-relationships between exchange rate volatility, exports, imports and productivity for several East Asian economies. Cointegration tests show no change in the long-run relationships among these variables throughout the crisis. Finally, Daly [4] documents a significant increase in correlations and volatility transmission between equity markets during and after the 1997 stock market crash.

Equity market linkages amongst the markets of South East have been conducted in several studies [10], [14], [15]. The study by Huyghebaert and Wang [10], for instance, investigates the integration among seven major East Asia stock market from July 1, 1992 to June 30, 2003. The results show that the 1997 - 1998 Asian financial crises did not enhance the co-movement of stock market in East Asia. However, due to different characteristics between the two crises, the GFC might be expected to cause some changes to the linkages amongst Southeast Asian equity markets. To contribute to the above literature this paper aims to investigate the long-term relationships among six countries in the Southeast Asian region, including Malaysia, Singapore, Thailand, Indonesia, the Philippines and Vietnam under impacts of the GFC. The paper fills a gap in the literature amongst emerging markets by examining the impacts of the GFC on the emerging markets of South East Asia, and moreover, it extends previous studies by including the Vietnamese equity market in the sample.

\section{Methodology AND Data Collection}

In the paper, long-run relationships among equity markets in the South East Asian region are examined by employing unit root tests, bivariate and multivariate cointegration tests, and cointegration tests with a present of structural break. Particularly, unit root tests are firstly employed to examine the stationary of the time series variables. Both Augmented Dickey Fuller test [16] and Phillip Perron [17] test are used in the paper. Next, cointegration techniques including bivariate method suggested by Engle and Granger [18] and multivariate method suggested by Johansen [19], [20] are performed to analyze cointegration among markets. However, as discussed by Gregory and Hansen [21], the power of cointegration test is reduced if a break in the relationship occurs; therefore, a unit root test with a present of a break suggested by Zivot and Andrew [22] and cointegration tests allowing for breaks in the cointegration relationship proposed by Gregory and Hansen [21] are employed in the paper.

The study uses daily MSCI market indices of Bursa Malaysia Stock Exchange (ML), Singapore Stock Exchange (SG), Bangkok Stock Exchange (TL), Indonesia Stock Exchange (IND), Philippine Stock Exchange (PP) and Ho Chi Minh Stock Exchange (VN) collected on DataStream from the 30 November 2006 to the end of 2010 (1067 observations of each market). The rationality for choosing data set is based on the availability of data on the source. Both the logarithm of market indices and the different of logarithm of market indices (market returns) are examined.

\section{Summary Statistics}

We begin our investigation into stock market integration by examining the summary statistics of the stock market levels (Table 1). The average price indices for all the Asian markets in the sample are approximately in the same range with the exception of the Singapore equity market which reported the highest returns over 2006-2010.The market indices with the exception of the Vietnam burse all report a negative but insignificant 'skewness'. The characteristics of the stock market returns as described above provide a general comparison for the Asian stock markets. However inference on the integration of stock markets is restricted to examining whether distributional features are similar. These measures are therefore not an adequate measure of stock market integration. Before we test for the latter we should investigate the extent to which the stock markets under consideration display co-movements between their indices.

A simple test here is to investigate the co-movement between stock market indices by considering the degree to which the indices are correlated over time. The results in Table 2 indicate a significant degree of correlation amongst the market indices with the exception of Vietnam. The highest correlation is found between Thailand and Malaysia while the lowest recorded relationship exists between the market indices of Vietnam and Indonesia. However, one drawback of this test is that it is a static test, measuring only short-run stock market integration, these measures are not adequate to investigate long-run relationships across markets [23].

Fig. 1. shows a plot on movements of the logarithm of equity market indices over the sample period. 

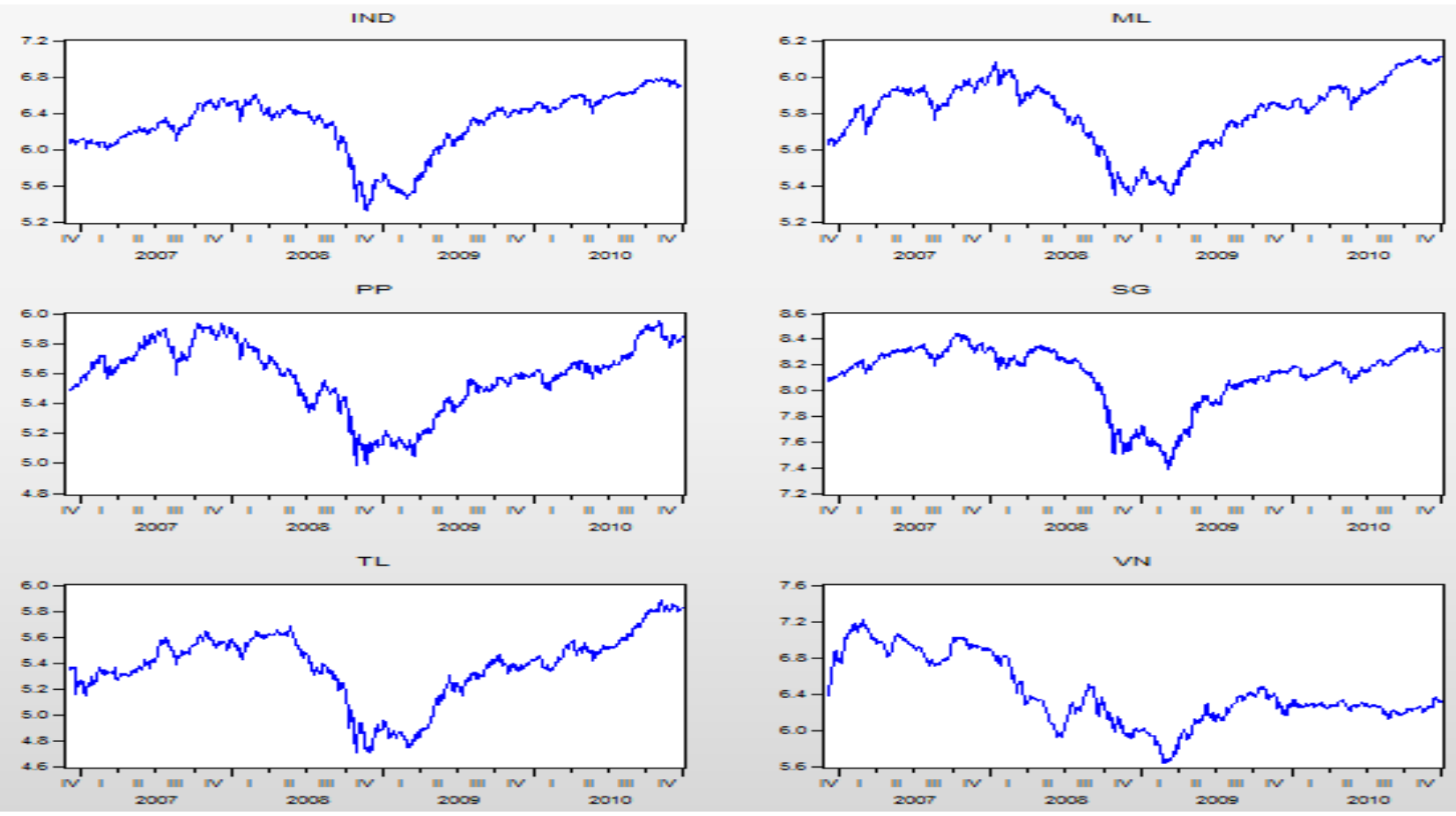

Fig. 1. Movements of the logarithm of the selected equity market indices

TABLE I: CHARACTERISTICS OF THE LOGARITHM OF THE MARKET INDICES

\begin{tabular}{|l|c|c|c|c|c|c|}
\hline & IND & ML & PP & SG & TL & VN \\
\hline Mean & 6.27 & 5.80 & 5.58 & 8.12 & 5.37 & 6.41 \\
\hline Median & 6.36 & 5.85 & 5.61 & 8.19 & 5.41 & 6.29 \\
\hline Skewness & -0.92 & -0.72 & -0.62 & -1.30 & -0.70 & 0.42 \\
\hline Kurtosis & 3.27 & 2.73 & 2.67 & 3.78 & 3.12 & 2.23 \\
\hline Jarque-Bera & 155 & 96 & 73 & 331 & 89 & 57 \\
\hline
\end{tabular}

TABLE II: CORRELATION MATRIX OF THE MARKET INDICES

\begin{tabular}{|c|c|c|c|c|c|c|}
\hline & IND & ML & PP & SG & TL & VN \\
\hline IND & 1 & 0.928 & 0.823 & 0.838 & 0.944 & 0.258 \\
ML & 0.928 & 1 & 0.940 & 0.913 & 0.954 & 0.466 \\
PP & 0.823 & 0.940 & 1 & 0.925 & 0.892 & 0.670 \\
SG & 0.838 & 0.913 & 0.925 & 1 & 0.907 & 0.647 \\
TL & 0.944 & 0.954 & 0.892 & 0.907 & 1 & 0.371 \\
VN & 0.258 & 0.466 & 0.67 & 0.647 & 0.371 & 1 \\
\hline
\end{tabular}

\section{RESUlts OF THE HyPOTHESIS TESTING}

\section{A. Unit roots tests}

The first step in cointegration is to test whether the variables in question are stationary or moving with time. If a variable is non-stationary in time then it is said to have a unit root. The standard tests for stationary or the existence of a unit root are the augmented Dickey-Fuller (ADF) and Phillip Perron (PP) tests.

The unit root testing procedure applies both an intercept and an intercept with trend; our results for the latter are reported in Table 3. The results indicate the existence of unit roots in the levels for all the indices (i.e. the null hypothesis cannot be rejected). Both the ADF and PP tests indicate no evidence to support the presence of a unit root in first differences of the stock price indices which suggests that the variables are stationary or (I1) in their first differences.
TABLE III: RESUlTS OF THE AUGMENTED DICKEY - FULLER AND PHILLIP PERRON UNIT ROOT TESTS FOR THE LEVEL AND THE FIRST DIFFERENT OF THE LOGARITHM OF THE MARKET INDICES

\begin{tabular}{|c|c|l|l|l|}
\hline \multirow{2}{*}{ Index } & \multicolumn{2}{|c|}{ ADF test } & \multicolumn{2}{c|}{ PP test } \\
\cline { 2 - 5 } & Level & 1st difference & Level & 1st difference \\
\hline IND & $-1.28(1)$ & $-28.47(0)$ & $-1.24(8)$ & $-28.33(12)$ \\
ML & $-0.90(1)$ & $-29.19(0)$ & $-0.84(2)$ & $-29.17(4)$ \\
PP & $-1.27(1)$ & $-28.68(0)$ & $-1.10(14)$ & $-28.45(17)$ \\
SG & $-0.98(0)$ & $-32.40(0)$ & $-1.00(4)$ & $-32.40(5)$ \\
TL & $-0.89(0)$ & $-33.40(0)$ & $-0.88(11)$ & $-33.41(11)$ \\
VN & $-1.89(4)$ & $-13.09(3)$ & $-2.04(16)$ & $-24.61(12)$ \\
\hline
\end{tabular}

Note: The critical values for both the ADF and PP tests are $-3.97,-3.41$, and -3.13 at $1 \%, 5 \%$ and $10 \%$ level, respectively. In the ADF test, the lag lengths are selected by the Schwarz Info Criteria with a maximum lag of 27. In the

PP test, the spectral estimation method is the Barlett Kernel and the Bandwidth selection is Newey-West.

\section{B. Cointegration Test}

A long-run relationship between two stock market indices, $\mathrm{j}$ and $\mathrm{k}$, can be represented by:

$$
\operatorname{Ln}\left(P_{t}^{j}\right)=a_{0}+a_{1} \operatorname{Ln}\left(P_{t}^{k}\right)+e_{t}
$$

where the stock market integration in the long-run implies a linear relationship between the natural logarithms of the portfolio price indices, $\operatorname{Ln}(\mathrm{Pj})$ and $\mathrm{Ln}(\mathrm{Pk})$. This is a test for the cointegration of two variables. If $\operatorname{Ln}(\mathrm{Pj})$ and $\mathrm{Ln}(\mathrm{Pk})$ are cointegrated, the error term $e_{t}$ in the above equation is stationary and there exists a long-run equilibrium relationship between the two series. If, as is typical for financial time series, $\operatorname{Ln}(\mathrm{Pj})$ and $\mathrm{Ln}(\mathrm{Pk})$ are both non-stationary and their first differences $\mathrm{Rj}$ and $\mathrm{Rk}$ are stationary, they are integrated of the order one, I(1). When each price index is $I(1)$ and there is a linear combination of market indices that are stationary, the indices are said to be cointegrated and hence there exists a long-run relationship 
between the indices which in turn suggests that the stock markets are integrated. In order to gain more insight into the integration of the above markets, we apply co integration techniques to determine the presence of any long-run relationships, which may have existed over the period. The existence of highly correlated long-run relationships between markets indicates that there exist little gains from diversifying amongst these markets.

In our first test for co integration we conduct a bi-variate cointegration test suggested by Engle and Granger [18], performed for a pair of markets. The second test, our multivariate cointegration suggested by Johansen [20], examines whether a vector of cointegration exists among the markets under consideration. Based on the plot of movements of stock price indices in Fig. 1, we assume that an intercept is included in equation models. Table 4 displays the results of the bi-variate tests amongst the markets in the region. The results reveal some evidence of bi-directional relationships such as Indonesia and Thailand; Malaysia and Thailand; Malaysia and Philippine; Singapore and Philippine; and Indonesia and Malaysia. Mono-direction relationship is only found in the equity markets of Philippine to Thailand. It is also noteworthy that no cointegrating relation is found in the case of the Vietnam.

TABLE IV: RESULTS OF T-STATISTICS OF BIVARIATE COINTEGRATION TEST BETWEEN THE EQUITY MARKETS

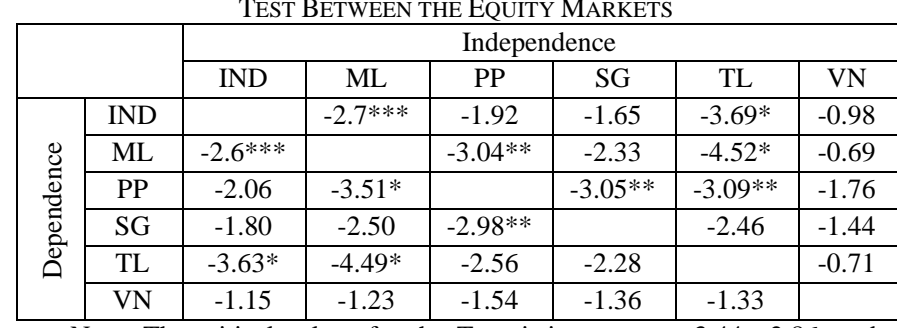

Note: The critical values for the T-statistic tests are $-3.44,-2.86$, and -2.56 at $1 \%, 5 \%$ and $10 \%$ level, respectively. A lag length is selected based on the SIC value and a maximum lag is $21 . *$, ** and *** denote rejection of the hypothesis at the $1 \%, 5 \%$ and $10 \%$ level, respectively.

TABLE V: LAG LENGTH SELECTION

\begin{tabular}{lccccc}
\hline $\begin{array}{l}\text { Data } \\
\text { Trend: }\end{array}$ & \multicolumn{1}{c}{ None } & \multicolumn{1}{c}{ None } & Linear & Linear & Quadratitc \\
\hline Rank or No Intercept & Intercept & Intercept & Intercept & Intercept \\
\hline $\begin{array}{l}\text { No. of } \\
\text { CEs }\end{array}$ & No Trend & No Trend & No Trend & Trend & Trend \\
\hline \multicolumn{7}{l}{ Akaike Information } & Criteria by Rank (rows) & and Model (columns) \\
0 & -33.068 & -33.068 & -33.058 & -33.058 & -33.048 \\
1 & -33.081 & -33.084 & -33.076 & -33.074 & -33.066 \\
2 & -33.080 & $-33.085^{*}$ & -33.080 & -33.077 & -33.070 \\
3 & -33.073 & -33.077 & -33.072 & -33.075 & -33.070 \\
4 & -33.056 & -33.066 & -33.064 & -33.065 & -33.061 \\
5 & -33.037 & -33.045 & -33.043 & -33.050 & -33.048 \\
6 & -33.014 & -33.022 & -33.022 & -33.027 & -33.027 \\
\hline
\end{tabular}

Note: The lag length of the cointegrating model is based on the minimum value of the Akaike Information Criteria (AIC). * denotes information of lag length selection and appropriate model.

In the second cointegration test, the multivariate method is applied; here the order of the Vector Autoregressive Model (VAR) should be determined by either the Akaike Information Criteria (AIC) or the Schwarz Information Criteria (SIC). Based on the SIC results in Table 5, 2 lag length was chosen for the equity market indices in the sample.

TABLE VI: MUlTIVARIATE COINTEGRATION RESUlTS

\begin{tabular}{lcccc}
\hline \multicolumn{4}{l}{ Unrestricted Cointegration Rank Test (Trace) } \\
\hline \multicolumn{5}{l}{ Hypothesized } \\
No. of CE(s) & Eigenvalue & Statistic & $\begin{array}{c}0.05 \\
\text { Critical } \\
\text { Value }\end{array}$ & Prob.** \\
\hline None * & 0.043 & 116.961 & 103.847 & 0.005 \\
At most 1 & 0.030 & 70.231 & 76.973 & 0.146 \\
At most 2 & 0.016 & 38.082 & 54.079 & 0.568 \\
At most 3 & 0.015 & 20.561 & 35.193 & 0.691 \\
At most 4 & 0.003 & 4.746 & 20.262 & 0.987 \\
At most 5 & 0.001 & 1.436 & 9.165 & 0.885 \\
\hline
\end{tabular}

Unrestricted Cointegration Rank Test (Maximum Eigenvalue)

\begin{tabular}{lcccc}
\hline Hypothesized & & Max-Eigen & $\begin{array}{c}0.05 \\
\text { Critical }\end{array}$ & \\
No. of CE(s) & Eigenvalue & Statistic & Value & Prob.** \\
\hline None * & 0.043 & 46.730 & 40.957 & 0.010 \\
At most 1 & 0.030 & 32.149 & 34.806 & 0.100 \\
At most 2 & 0.016 & 17.521 & 28.588 & 0.617 \\
At most 3 & 0.015 & 15.815 & 22.300 & 0.312 \\
At most 4 & 0.003 & 3.310 & 15.892 & 0.984 \\
At most 5 & 0.001 & 1.436 & 9.165 & 0.885 \\
\hline
\end{tabular}

Note: The specification of the cointegration test is with intercept no trend and 2 lag intervals are chosen. * denotes rejection of the hypothesis at the $5 \%$ level based on the MacKinnon-Haug-Michelis (1999).

Table 6 provides test results for the six markets in the sample based on a VAR model test for multivariate cointegration. Both the Trace and Max - Eigen value indicate a rejection of the null hypothesis of no cointegration. The results reveal evidence for the existence for one co-integrating vector amongst the markets. The results support our previous test for the existence of bivariate relationships in confirming the existence of cointegration or long run relationships amongst the Southeast Asian equity markets.

\section{Cointegration Test with the Present of Structural Breaks}

As stated by Gregory and Hansen [21], a co-integration test is significantly decreased if a break in the time series data occurs so they suggest a co-integration test allowing for a single break in the relationship. Accordingly, a break date is, firstly, found by employing the test suggested by Zivot and Andrew [22] and then, cointegration between markets is examined by taking into account the existence of structural breaks of time series data.

Based on the method of Zivot and Andrew [22], the paper determines a break date of the equity market levels under the impacts of the GFC over the period 2006 - 2010. Details of the breaking dates of each market are shown in Table 7. The results show that although the sub -prime crisis emerged in the US in the mid of 2007, it significantly impacts on the Southeast Asia equity market in the first half of the year 2008. The results are in line with the studies of Syllignakis and Kouretas[24] and Bartram and Bodnar [3] who state that the GFC deteriorated most markets in early to mid 2008.

The t-statistic for the Zivot and Andrew test shown in Table 7 reveal that the null hypothesis of the non-stationary of variable cannot be rejected in all markets in the modeled equations suggesting that the variables are stationary or I(1) in their first differences. 
TABLE VII: RESULTS ON ZIVOT AND ANDREWS UNIT ROOT TESTS ON MARKET LEVELS WITH A PRESENT OF STRUCTURAL BREAKS

\begin{tabular}{ccc}
\hline & Break date & t-statistic \\
\hline PP & $13 / 02 / 2008$ & -3.427 \\
TL & $22 / 05 / 2008$ & -4.037 \\
ML & $20 / 05 / 2008$ & -3.53 \\
SG & $25 / 07 / 2008$ & -3.207 \\
IND & $01 / 08 / 2008$ & -3.411 \\
VN & $12 / 02 / 2008$ & -4.610 \\
\hline
\end{tabular}

Note: The maximum number of lag is 25 and the lag length selection is based on the AIC value. The critical values for t-statistic allowing for a break in intercept are -5.43 and -4.8 at $1 \%$ and $5 \%$ level respectively.

Based on the Zivot and Andrew tests, the Gregory and Hansen cointegration test is performed and shown in Table 8. Results find some evidence supports on cointegration relationship among the markets. Specifically, the results support bi-direction linkages between the equity indices of Thailand and Indonesia, Malaysia and Philippines; between Indonesia and Philippine, and between Malaysia and Thailand. An interesting result is found in the relationship between the Philippine and Thailand's equity market which a bi-directional linkage is supported in the Gregory and Hansen test while a mono-directional linkage is found between the market in the Engle and Granger test. Another surprising result is revealed in the relationship between the Vietnam and the other equity markets with evidence on the existences of mono-directional relationships between the Vietnam and the regional markets. In other words, the movement of the Vietnam's equity market has a long-run relationship with other markets in the sample but not vise versa. This could be explained by the fact that the Vietnam's equity market is fairly new and younger compared to the neighboring markets, moreover, the Vietnam burse is relatively isolated than other markets due to the strict regulations imposed by Government.

TABLE VIII: RESUltS OF COINTEGRATION TESTS WITH THE PRESENT OF A STRUCTURAL BREAK

\begin{tabular}{|c|c|c|c|c|c|c|c|}
\hline & \multicolumn{6}{|c|}{ Independence } \\
\hline & & IND & ML & PP & SG & TL & VN \\
\hline \multirow{6}{*}{ 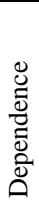 } & IND & & -4.04 & $-4.73 * *$ & -3.86 & $-4.71 * *$ & -2.69 \\
\hline & ML & -4.05 & & $-5.83^{*}$ & -3.9 & $-5.18 *$ & -2.42 \\
\hline & PP & $-4.90 * *$ & $-6.01 *$ & & -3.41 & $-5.93 *$ & -3.24 \\
\hline & SG & -4.01 & -4.06 & -3.27 & & $-4.61 * *$ & -2.71 \\
\hline & $\mathrm{TL}$ & $-4.62 * *$ & $-5.15^{*}$ & $-5.55^{*}$ & $-4.3 * * *$ & & -2.30 \\
\hline & $\mathrm{VN}$ & $-4.93 * *$ & $-4.81 * *$ & $-4.50 * * *$ & $-4.88 * *$ & $-4.71 * *$ & \\
\hline
\end{tabular}

Note: The table reports the T-statistic of the ADF test for the cointegration with regime shift in level. The lag length is chosen by Akaike Criteria. The critical value of the T-statistic is $-5.13,-4.61$ and -4.34 at the $1 \%, 5 \%$ and $10 \%$ level, respectively. $*$, ** and $* * *$ denote rejection of the null hypothesis at the $1 \%, 5 \%$ and $10 \%$, respectively.

The empirical results of the paper, to a certain extent, improve the findings in the study by Daly [4] who found little evidence in support of cointegration amongst the Southeast Asian markets since the October 1987 crisis period. On the other hand, our results are supported by Click and Plummer [5] who found evidence of a co-integrating vector among five Asian stock markets in the period after the Asian financial crisis. It may be concluded that benefits of international portfolio diversification across equity markets in the region are reduced but not eliminated.

\section{SUMmary AND CONCLUSIONS}

In summary the evidence from performing a battery of cointegration tests indicates that a number of long-run relationships are found to exist amongst the six equity market indices of Indonesia, Malaysia, Thailand, Singapore, Malaysia and Vietnam. Our empirical findings support a bi-directional relationship between the equity market of Thailand and Indonesia; Thailand and Singapore; Indonesia and Philippine, Malaysia and Philippine; and Thailand and Malaysia in both pair-wise cointegration tests with and without the presence of a structural break. With the introduction of structural breaks we note that evidence of cointegration between the markets of the Philippines and Thailand changes from one-directional relationship to bi-directional relationship. The mono-directional linkages are found in the relationship between the Vietnam and other markets. This result may be explained by the fact that the Vietnam's equity market is fairly new and young compared to the other regional markets in this study; moreover, the Vietnam equity market appears to be relatively isolated from the other markets because of strict regulations imposed by the Government. The lack of cointegration between the Vietnam burse and its neighboring markets requires investigation. One is tempted to explain this lack of integration between Vietnam and its nearby markets on a number of endemic problems including the highly speculative nature of the Vietnamese stock markets and the lack of a strong governance structure in the State Securities Commission (SSC) within the Ministry of Finance. It is also questionable whether Vietnam actually needs two stock exchanges. Indeed, it may be desirable for Vietnamese firms to be encouraged to list with regional exchanges in Hong Kong and Singapore where much higher standards of corporate governance and transparency are enforced.

\section{ACKNOWLEDGMENT}

T. P. Thao would like to thank Dr. Anil Mishra, University of Western Sydney for giving data used for the study and initial comments.

\section{REFERENCES}

[1] H. H. AuYong, C. Gan, and S. Treepongkaruna, "Cointegration and causality in the Asian and emerging foreign exchange markets: Evidence from the 1990s financial crises, "International Review of Financial Analysis, vol. 13, pp. 479-515, 2004.

[2] B. N. Huang, C. W. Yang, and J. W. S. Hu, "Causality and cointegration of stock markets among the United States, Japan and the South China Growth Triangle. "International Review of Financial Analysis, vol. 9, pp. 281-297, 2000.

[3] S. M. Bartram and G. M. Bodnar, "No place to hide: The global crisis in equity markets in 2008/2009, " Journal of International Money \& Finance, vol. 28, pp. 1246-1292, 2009.

[4] K. J. Daly, "Southeast Asian Stock Market Linkages: Evidence from Pre- and Post-October 1997, " ASEAN Economic Bulletin, vol. 20, pp. 73-85, 2003.

[5] R. W. Click and M. G. Plummer, "Stock market integration in ASEAN after the Asian financial crisis, "Journal of Asian Economics, vol. 16, pp. 5-28, 2005.

[6] E. Marais and S. Bates, "An empirical study to identify shift contagion during the Asian crisis, " Journal of International Financial Markets, Institutions and Money, vol. 16, pp. 468-479, 2006.

[7] B. Arshanapalli and J. Doukas, "International stock market linkages: Evidence from the pre- and post-October 1987 period, " Journal of Banking \& Finance, vol. 17, pp. 193-208, 1993. 
[8] D. E. Allen and G. MacDonald, "The long-run gains from international equity diversification: Australian evidence from cointegration tests, "Applied Financial Economics, vol. 5, pp. 33-42, 1995.

[9] B. M. Lucey and S. Voronkova, "Russian equity market linkages before and after the 1998 crisis: Evidence from stochastic and regime-switching cointegration tests, "Journal of International Money and Finance, vol. 27, pp. 1303-1324, 2008.

[10] N. Huyghebaert and L. Wang, "The co-movement of stock markets in East Asia: Did the 1997-1998 Asian financial crisis really strengthen stock market integration?". China Economic Review, vol 21, pp. 98-112, 2010.

[11] W. Cheung, S. Fung, and S. C. Tsai, "Global capital market interdependence and spillover effect of credit risk: evidence from the 2007-2009 global financial crisis, " Applied Financial Economics, vol. 20 , pp. $85-103,2010$

[12] G. M. Chen, M. Firth, and O. M. Rui, "Stock market linkages: Evidence from Latin America, "Journal of Banking \& Finance, vol 26, pp. 1113-1141, 2002.

[13] C. C. Nieh, "The effect of the Asian financial crisis on the relationships among open macroeconomic factors for Asian countries, "Applied Economics, vol. 34, pp. 491-502, 2002.

[14] K.-M. Wang and T.-B. N. Thi, "Does contagion effect exist between stock markets of Thailand and Chinese Economic Area (CEA) during the Asian flu, " Asian Journal of Management and Humanity Sciences, vol. 1, pp. 16-36, 2006.

[15] C. S. Tai, "Market integration and contagion: Evidence from Asian emerging stock and foreign exchange markets, " Emerging Markets Review, vol. 8, pp. 264-283, 2007.

[16] D. A. Dickey and W. A. Fuller, "Distribution of the Estimators for Autoregressive Time Series With a Unit Root, "Journal of the American Statistical Association, vol. 74, pp. 427, 1979.

[17] P. C. B. Phillips and P. Perron, "Testing for a unit root in time series regression, "Biometrika, vol. 75, pp. 335-346, 1988

[18] R. F. Engle and C. W. J. Granger, "Co-Integration and Error Correction: Representation, Estimation, and Testing, "Econometrica, vol. 55, pp. 251-276, 1987.

[19] S. Johansen, "Statistical analysis of cointegration vectors, "Journal of Economic Dynamics and Control, vol. 12, pp. 231-254, 1988.

[20] S. Johansen, "Estimation and hypothesis testing of cointegration vectors in gaussian vector autoregressive models, "Econometrica, vol. 59, pp. 1551, 1991

[21] A. W. Gregory and B. E. Hansen, "Residual-based tests for cointegration in models with regime shifts, "Journal of Econometrics, vol. 70, pp. 99-126, 1996.

[22] E. Zivot and D. W. K. Andrews, "Further Evidence on the Great Crash, the Oil-Price Shock, and the Unit-Root Hypothesis, "Journal of Business \& Economic Statistics, vol. 20, pp. 25 - 44, 2002.
[23] X. V. Vo and K. J. Daly, "International financial integration: an empirical investigation into Asian equity markets pre and post -1997 Asian financial crisis," in Asia Pacific financial markets in comparative perspective : issues and implications for the 21 st century, T.A. Fetherston and J. Batten, Editors, 2005, Elsevier: Amsterdam. pp. 75-100.

[24] M. N. Syllignakis and G. P. Kouretas, "Dynamic correlation analysis of financial contagion: Evidence from the Central and Eastern European markets," International Review of Economics \&amp; Finance, vol. 20, pp. 717-732, 2011.

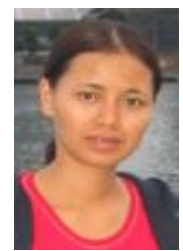

Tran Phuong Thao was born in Vietnam on September $29^{\text {th }}, 1978$. She has taken the Bachelor and Master Degree from University of Economics Ho Chi Minh City, Vietnam in 2000 and 2003, respectively. She has currently been a candidate of the Doctoral of Business Administration Program at University of Western Sydney since April 2009.

She has been a lecturer at University of Economics Ho Chi Minh City, Vietnam since 2004 and she is currently a Vice Dean of the Securities Business Department, Faculty of Banking of the University. She participated in writing several textbooks for economic students such as Financial Market ${ }^{1}$,Securities Investment and Analysis ${ }^{2}$, and she was a member of several scientific research projects granted by the University of Economics Ho Chi Minh City titled "Bond Market in Vietnam" in 2006; or "Building option contracts for the securities market in Vietnam" in 2009 Her research interests are financial market and institution, Investment and Valuation.

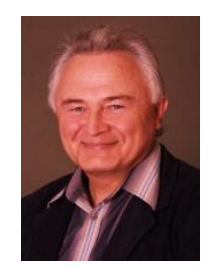

Dr. Kevin Daly is Associate Professor and Director of Academic Programs in the School of Economics and Finance, University of Western Sydney.

Kevin's research interests revolve around finance and open economy macroeconomics with particular attention focused on the implications of interaction between the financial sectors and the real sectors of economic activity. Related themes include the composition of domestic investment, foreign direct investment, portfolio foreign investment, superannuation investments, cross-border capital movements, emerging markets financial development, global financial integration and the links between finance and poverty. 